\title{
PENGARUH PENILAIAN PRESTASI KERJA KARYAWAN TERHADAP PROMOSI JABATAN PADA DINAS PERHUBUNGAN KOTA PALEMBANG
}

\author{
Maya Dini \\ Dosen POLTEK ANIKA
}

\begin{abstract}
ABSTRAK
Penelitian ini bertujuan untuk Untuk mengetahui pengaruh penilaian prestasi kerja secara parsial terhadap promosi jabatan pada Dinas Perhubungan Kota Palembang .Untuk mengetahui pengaruh penilaian prestasi kerja secara seimultan terhadap promosi jabatan pada Dinas Perhubungan Kota Palembang.

Metode yang digunakan dalam penelitian ini adalah menggunakan teknik probabilitas dengan cara random sampling (Metode sampel acak sederhana), yaitu dengan metode pemilihan sampel di mana setiap anggota populasi mempunyai peluang yang sama untuk dipilih menjadi anggota sampel. Teknik pengumpulan data dilakukan melalui data primer yaitu Dinas Perhubungan Kota Palembang. dan data sekunder yaitu data yang diperoleh dari literatur dan buku-buku yang ada hubungannya dengan masalah yang akan diteliti. Alat analisis yang digunakan adalah uji regresi sederhana dengan skala pengukuran skala likert.

Hasil Penelitian menunjukkan bahwa besarnya coefisien $Y=12,826+0,459 x$ dan menunjukan besarnya koefisien regresi uji t sebesar 0,01 dan $R$ Square $\left(R^{2}\right)$ yaitu menunjukan nilai koefisien determinasi. Angka ini akan di ubah ke bentuk persen yang artinya persentase sumbangan pengaruh variabel dependent. Pengaruh penilaian prestasi kerja secara parsial terhadap promosi jabatan pada Dinas Perhubungan Sumatera Selatan sebesar 65,9\% sedangkan sisanya dipengaruhi oleh variabel lain yang tidak dimasukkan dalam penelitian ini.
\end{abstract}

\section{Kata Kunci : Penilaian Prestasi kerja, Promosi Jabatan}

\section{PENDAhuluan}

\subsection{Latar Belakang}

Sumber daya manusia sangat penting bagi organisasi profit maupun non profit baik yang bergerak dalam bidang jasa maupun bidang produksi. Sumbe daya manusia dituntun untuk bekerja secara efektif dan efisien. Sumber daya manusia yang dimiliki organisasi perlu memiliki kemampuan dan ketrampilan dalam bekerja. Sumber daya manusia dituntut untuk bekerja maksimal dalam menggapai tujuan perusahaan atau organisasi yang telah ditetapkan, sehingga organisasi perlu memiliki manajemen dalam pengelolaan sumber daya manusia. Manajemen sumber daya manusia merupakan ilmu dan seni yang mengatur hubungan dan peranan tenaga kerja agar efektif dan efisien untuk membantu perusahaan, karyawan,dan masyarakat. Sumber daya manusia yang dimiliki organisasi perlu dikelola atau dimanajemenkan untuk menggapai tujuan yang telah ditetapkan oleh perusahaan.
Perusahaan perlu mengelola sumber daya yang dimiliki dengan baik agar perusahaan atau organisasi dapat menghasilkan hal yang positif bagi perusahaan atau organisasi yang sesuai dengan fungsi - fungsi manajemen sumber daya manusia. Fungsifungsi manajemen sumber daya manusia terdiri dari perencanaan, pengorganisasian, pengarahan, pengendalian, pemberian kompensasi, pengintegrasian, pemeliharaan, kedisiplinan, dan pemberhentian. Dari beberapa fungsi tersebut, perusahaan harus mengelola sumber daya manusianya untuk bersaing dalam dunia kerja. Maka dari hal itu, perusahaan perlu mengadakan pelatihan dalam pengelolaan sumber daya manusia. Selain itu, perusahaan harus memotivasi karyawan untuk meningkatkan prestasi kerja dengan menggunakan hadiah promosi jabatan.

Adapun pengertian prestasi kerja menurut para ahli yaitu, menurut Hasibuan, bahwa Prestasi kerja merupakan suatu hasil kerja yang dicapai seseorang dalam 
melaksanakan tugas-tugas yang dibebankan kepadanya yang didasarkan atas pengalaman, kecakapan, kesungguhan, serta waktul. Sedangkan menurut Sutrensno, bahwa Prestasi kerja merupakan sebagian hasil yang telah dicapai seseorang dari tingkah laku kerjanya dalam melaksanakan aktivitas kerjanya. Menurut Kaynaz yang dikutip Prasasti, bahwa prestasi kerja berfungsi sebagai alat komunikasi bagi karyawan untuk melihat kinerja selama ini. Dengan prestasi kerja, maka manajer dapat mengetahui kinerja karyawan, sehingga manajer atau perusahaan dapat memberikan imbalan sesuai dengan kinerja karyawan masing sesuai dengan kemampuan atau prestasi mereka. Prestasi kerja juga dapat mengetahui seberapa besar tanggung jawab karyawan terhadap tugas yang diberikan oleh perusahaan atau manajer. Dengan melalui prestasi kerja, maka perusahaan atau manajer dapat mengetahui sebebrapa baik karyawan dalam melaksanakan tangggung jawab dalam melaksanakan tugas yang diberikan. Selain itu, prestasi kerja dapat untuk mengetahui kelamahan dan potensi karyawan dalam perusahaan. Dengan prestasi kerja, perusahaan dapat merencanakan dalam pengembangan sumber daya manusia dalam menghadapi perubahan masa yang akan datang. prestasi kerja dapat mempengaruhi kompesasi dan promosi jabatan.

Berdasarkan hasil evaluasi kinerja Dinas Perhubungan Sumatera Selatan yang adalah sebagai berikut

Tabel. 1

Hasil evaluasi terhadap kinerja karyawan pada tahun 2018-2020

\begin{tabular}{|c|c|c|}
\hline Tahun & Nilai Hasil Evaluasi & Predikat Penilaian \\
\hline 2018 & 68,34 & B \\
\hline 2019 & 70,10 & BB \\
\hline 2020 & 73,06 & BB \\
\hline
\end{tabular}

Sumber : Laporan Kinerja Dinas Perhubungan Kota Palembang

Dari tabel 1 terlihat bahwa nilai hasil evaluasi kinerja Dinas Perhubungan Sumatera Selatan mengalami peningkatan dari tahun ke tahun dan mendapat predikat BB. Peran Sumber Daya Manusia Dinas Perhubungan Sumatera Selatan menjadi faktor utama dalam pencapaian prestasi ini. Sebagaimana yang dikemukakan oleh Robbins dan Timothy (2017) bahwa kinerja atau prestasi organisasi bergantung pada kinerja individu atau anggota organisasi. Kinerja karyawan merupakan hasil sinergi dari sejumlah faktor (Wirawan, $2012: 7-8$ ), yang terdiri dari, faktor internal karyawan, faktor lingkungan internal organisasi dan faktor lingkungan eksternal organisasi. Faktor -faktor internal karyawan bersinergi dengan faktor-faktor lingkungan internal organisasi. Sinergi ini mempengaruhi perilaku kerja karyawan yang kemudian mempengaruhi kinerja karyawan. Kinerja karyawan kemudian menentukan kinerja organisasi. Untuk mencapai hasil evaluasi kinerja Dinas Perhubungan Sumatera Selatan yang lebih baik lagi, salah satu dari delapan area perubahan rencana strategis reformasi birokrasi Dinas Perhubungan
2018-2020 adalah Penataan Sumber Daya Manusia. Penataan Sumber Daya Manusia bukanlah hal yang mudah untuk dilakukan. tugas seorang pimpinan adalah mengontrol dan mengembangkan faktor lingkungan internal organisasi dan faktor internal karyawan. Hal ini dapat dilakukan dengan jalan penilaian prestasi kerja. Dengan adanya Penilaian Prestasi Kerja, diharapkan dapat meningkatkan penerapan sistem, proses dan prosedur kerja yang jelas, efektif, efisien, cepat, terukur, transparan, partisipatif.. Penilaian Prestasi Kerja adalah suatu proses penilaian secara sistematis yang dilakukan oleh pejabat penilai terhadap sasaran kerja pegawai dan prilaku kerja . Penilaian Prestasi Kerja diharapkan dapat digunakan alat ukur untuk dalam hal promosi jabatan dan kinerja pegawai itu sendiri. Dengan menggunakan penilaian prestasi kerja sebagai ukuran untuk promosi suatu jabatan, secara tidak langsung akan memberi dampak terhadap kinerja instansi itu sendiri. Penempatan pegawai pada suatu jabatan yang tepat akan meningkatkan prestasi kerja pegawai. 
Promosi jabatan merupakan sarana yang dapat mendorong karyawan untuk lebih baik atau lebih bersemangat dalam melakukan suatu pekerjaan dalam suatu lingkungan perusahaan. Pihak-pihak yang berkepentingan terhadap promosi jabatan adalah karyawan, manajer, perusahaan. Dengan adanya promosi jabatan, karyawan akan merasa dihargai, diperhatikan, dibutuhkan dan diakui kemampuan kerjanya oleh manajer sehingga mereka akan menghasilkan keluaran (output)yang tinggi. Bagi manajer, promosi jabatan yang diberikan kepadakaryawan sebagai reward atas kinerja yang dilakukan oleh karyawan dalam melaksanakan tanggungjawabnya. Bagi perusahaan, promosi jabatan bertujuan untuk meregenerasi sumber daya manusia yang dimiliki demi kelangsungan perusahaan tersebut. Kondisi promosi jabatan secara umum di beberapa perusahaan masih berdasarkan senioritas, dimana karyawan yang sudah berumur akan lebih mudah di prioritaskan dalam promosi jabatan. Tetapi ada juga perusahaan yang tidak menggunakan senioritas, dimana senioritas tidak menjamin sepenuhnya prestasi kerja yang lebih baik. Sering terjadi bahwa seseorang yang belum dapat dikategorikan senior ternyata mampu berprestasi lebih baik. Salah satu faktor yang mempengaruhi promosi jabatan adalah prestasi kerja.

Pada penelitian sebelumnya dilakukan penelitian di P.T Sanbe Farna Cimareme. Penelitian ini dibuat oleh Angga Harlisma Septianto. Penelitian ini memiliki tujuan untuk mengetahui seberapa besar penilaian prestasi kerja dan loyalitas karyawan terhadap promosi jabatan di P.T Sanbe Farna Cimareme Sedangkan penelitin yang sekarang melakukan penelitian Dinas Perhubungan Sumatera Selatan. Selanjutnya mengenai variabel, pada penelitian sebelumnya hanya menggunakan variabel prestasi kerja pada variabel independent dan variabel loyalitas pada varibel dependent. Dalam penelitian ini tetap menggunakan variabel penilaian prestasi kerja pada variabel independent, dan variabel dependentnya menambah dengan mengunakan variabel promosi jabatan. Berdasarkan latar belakang diatas, penelitian ini mengambil judul "Pengaruh
Penilaian Prestasi Kerja Terhadap Promosi Jabatan Pada Dinas Perhubungan Sumatera Selatan".

\subsection{Perumusan Masalah}

Berdasarkan uraian diatas, maka perumusan masalah dalam penelitian ini adalah Berdasarkan pada latar belakang penelitian yang telah diuraikan di atas maka permasalahan diatas dapat diidentifikasikan sebagai berikut :

1.2.1 Apakah Penilaian Prestasi Kerja mempunyai pengaruh secara parsial terhadap promosi jabatan pada Dinas Perhubungan Kota Palembang?

1.2.2 Apakah Penilaian Prestasi Kerja mempunyai pengaruh secara simultan terhadap promosi jabatan pada Dinas Perhubungan Kota Palembang?

\subsection{Tujuan Penelitian}

Adapun tujuan penelitian. yang dilakukan oleh penulis sebagai berikut :

1.3.1 Untuk mengetahui pengaruh penilaian prestasi kerja secara parsial terhadap promosi jabatan pada Dinas Perhubungan Kota Palembang

1.3.2 Untuk mengetahui pengaruh penilaian prestasi kerja secara seimultan terhadap promosi jabatan pada Dinas Perhubungan Kota Palembang

\section{TINJAUAN PUSTAKA}

\subsection{Landasan Teori}

\subsubsection{Pengertian Prestasi Kerja}

Penilaian prestasi kerja ini pada dasarnya merupakan salah satu faktor kunci guna mengembangkan suatu perusahaan secara efektif dan efisien. Penilaian prestasikerja juga memungkinkan para karyawan untuk mengetahui bagaimana prestasi kerja mereka, dan sejauh mana hasil kerja mereka dinilai oleh atasan. Kegiatan penilaian ini dapat memperbaiki keputusan-keputusan personalia dan memberi umpan balik kepada karyawan dalam pelaksanaan kerja mereka. Hal ini akandapat memotivasi mereka untuk kemajuan-kemajuan mereka di masa yang akan datang Berdasarkan uraian di atas 
maka pelaksanaan penilaian presatsi di dalam suatu organisasi sangatlah penting. Karena dengan penialian prestasi pihak manajemen dapat mengetahui tindakantindakan yang dapat di lakukan untuk meningkatkan keterampilan dari karyawan tersebutberikut beberapa pendapat yang di kemukakan oleh para ahli mengenai penilaian prestasi kerja. Penilaian prestasi kerja adalah suatu cara dalam melakukan evaluasi terhadap prestasi kerja para pegawai dengan serangkaian tolak ukur tertentu yang obyektif dan berkaitan langsung dengan tugas seseorang serta di lakukan secara berkala.

Menurut Harvard Business Essentials (2017:28) Penilaian kinerja adalah suatu metode formal untuk mengukur seberapa baik pekerja individual melakukan pekerjaan dalam hubungan dengan tujuan yang di berikan. Maksud utama penilaian kinerja adalah mengkomunikasikan tujuan personal, memotivasi kinerja baik, memberikan umpan balik konstruktif, dan menetapkan tahapan untuk rencana pengembangan yang efektif

Sementara itu Menurut Robert L. Mathis dan John penilaian kinerja (performance appraisal) adalah proses mengevaluasi seberapa baik karyawan melakukan pekerjaan mereka jika di bandingkan dengan seperangkat standar, dan kemudian mengkomunikasikan informasi tersebut pada karyawan. Sesuai dengan beberapa definisi di atas maka pengertian penilaian prestasi kerja karyawan dapat di padatkan sebagai berikut

1) Penilaian prestasi ini merupakan evaluasi terhadap prilaku prestasi kerja.dan potensi pengembangan yang telah di lakukan.

2) Penilaian prestasi ini pada dasarnya merupakan suatu proses mengestimasi dan menentukan nilai keberhasilan pelaksanaan tugas para karyawan.

3) Penilaian prestasi ini membandingkan realisasi nyata dengan standar (required performance) yang di capai karyawan.

4) Penilain presatsi dilaksanakan oleh manajer terhadap bawahannya.

5) Penilaian presatsi ini akan menentukan

selanjutnya.

kebijaksanaan

\subsubsection{Manfaat Penilaian Prestasi Kerja}

Selanjutnya manfaat penilaian prestasi kerja menurut Sedarmayanti (2017; 143) ditinjau dari berbagai perspektif pengembangan perusahaan, khususnya manajemen SDM yaitu:

1. Perbaikan Prestasi Kerja.

2. Penyesuaian Kompensasi.

3. Keputusan Penempatan.

4. Kebutuhan Latihan dan Pengembangan.

5. Perencanaan dan Pengembangan Karir.

6. Perbaikan Proses Susunan Pegawai.

7. Ketidakakuratan Informasi.

8. Kesalahan Desain Pekerjaan.

9. Kesempatan Kerja Yang Adil.

10. Tantangan Eksternal.

Penilaian prestasi kerja bermanfaat untuk program perbaikan prestasi kerja pegawai, promosi jabatan, kompensasi, pelatihan dan pengembangan, penempatan (replacement), desain pekerjaan, kecemburuan sosial, dan kompetisi.

\subsubsection{Faktor Yang Mempengaruhi Penilaian Prestasi Kerja}

Melaksanakan penilaian prestasi kerja yang baik bukanlah hal mudah. Ada berbagai faktor baik eksternal maupun internal yang akan mempengaruhi penilaian prestasi kerja karyawan. Berbedanya lingkungan dan bentuk organisasi serta kurangnya kemampuan dan motivasi penilaian dalam melaksanakan penilaian dapat mempengaruhi penilaian yang dilakukan hingga bisa mengakibatkan bias dalam penilaian, apalagi ukuran-ukuran yang digunakan bersifat kualitatif. Menurut Sedarmayanti $(2017 ; .144)$ adanya berbagai bias penilai yang umum terjadi, bias tersebut diantaranya adalah:

1. Hallo Effect.

2. Kesalahan Kecenderungan Terpusat.

3. Bias Terlalu Lunak dan Terlalu Keras.

4. Prasangka Pribadi.

5. Pengaruh Kesan Terakhir. 


\subsubsection{Indikator dalam Penilaian Prestasi Kerja \\ Selain menetapkan kriteria penilaian, ada juga yang harus ditetapkan pula, indikator-indikator apa saja yang dapat dinilai dalam melihat prestasi kerja seorang pegawai. Menurut Mangkunegara $(2014 ; 85)$ indikator-indikator dalam penilaian prestasi kerja yaitu: \\ 1. Kerjasama. \\ 2. Tanggung Jawab. \\ 3. Kepemimpinan. \\ 4. Kedisiplinan.}

\subsubsection{Pengertian Promosi Jabatan}

Promosi jabatan terjadi apabia seorang karyawan dipindahkan dari suatu pekerjaan kepekerjaan lain yang lebih tinggi dalam pembayaran, tanggung jawab atau level. Promosi jabatan yang dilakukan manajemen memberikan peranan penting bagi setiap karyawan, bahwa setiap karyawan menjadikan promosi jabatan sebagai harapan. Dengan adanya promosi jabatan, karyawan akan merasa dihargai, diperhatikan, dibutuhkan, dan diakui kemampuannya dalam bekerja di perusahaan. Dengan adanya romosi jabatan, karyawan akan termotivasi dalam pengembangan karirnya.

Menurut Hasibuan, bahwa promosi merupakan perpindahan karyawan dalam organisasi ke jabatan yang lebih tinggi, sehingga karyawan memiliki wewenang, hak, status, dan penghasilan yang besar. Dengan adanya promosi, karyawan akan mereasa dihargai terhadap tugas-tugas yang dikerjakan salam ini. Edwin B.Flipo yang dikutip Hasibuan, bahwa promosi merupakan perpindahan dari suatu jabatan ke jabatan lain yang mempunyai status dan tangggung jawabyang lebih tinggi. Biasanya perpindahan yang lebih tinggi disertai dengan gaji atau upah lainnya, walaupun tidak selalu demikian. Perpindahan jabatan ke jabatan yang tinggi juga disertai dengan tanggung jawab yang tinggi pula.

Promosi juga identik dengan kenaikan upah atau gaji. Semakin tinggi jabatan seseorang maka semakin tinggi pula tanggung jawab yang dipikul oleh seseorang. Setiap karyawan ingin dipromosikan sesuai dengan prestasi mereka sendiri. Promosi selalu diikuti dengan tugas dan tanggung jawab berat, sepertihalnya semakin tinggi pekerjaan semakin tinggi pula risiko yang dipikul oleh karyawan.

Promosi jabatan selalu identik dengan perpindahan. Dengan adanya promosi jabatan, maka tanggung jawab karyawan akan menjadi lebih besar dari pada sebelumnya, sehingga karyawan harus hati-hati dalam meperhitugkan dalam menggunakan hak dan wewenangnya di dalam organisasi. Dengan adanya promosi jabatan, maka tugas, tanggung jawab, gaji, faisilitas serta wewenang akan meningkat pula. Dapat disimpulkan bahwa promosi merupakan perpindahan suatu jabatan ke jabatan yang lebih tinggi dan memiliki kewajiban, hak, status, dan penghasilan yang lebih besar. Jika jabatan karyawan semakin tinggi maka karyawan tersebut memiliki pula tanggung jawab dan upah yang tinggi. Dengan adanya promosi jabatan, karyawan akan bekerja dengan semaksimal mungkin untuk mendapatkan jabatan yang lebih tinggi sebelumnya

\subsubsection{Unsur-Unsur dalam Promosi Jabatan}

Dalam promosi jabatan, organisasi harus mempertimbang secara matang terhadap promosi jabatan yang akan dilaksanakan. Dengan pembilan keputusan yang tidak maksimal, maka kerugian paling besar adalah di organisasi itu sendiri. Maka dari hal itu, organisasi harus mempertimbangkan unsur-unsur dalam promosi jabatan, yaitu:

1. Kecakapan Kerja

Kecakapan kerja merupakan hal yang harus dimiliki karyawan, karena dengan kecakapan kerja karyawan akan tangguh dan giat dalam melaksanakan tugas yang diberikan

2. Sinioritas

Orang yang telah bergabung lama dalam organiasi, lebih mengetahui keadaan organisasi dari pada orang baru. Senioritas selalu didahulukan dalam promosi jabatan

3. Pretasi Kerja Prestasi kerja merupakan hasil yang telah dicapai seseorang yang berdasarkan kemampuan, kecakapan, 
tanggung jawab, serta waktu yang digunakan. Dengan orang yang berprestasi, organisasi dapat maju apabila organisasi tersbut dipromosikan dalam jabatannya. Orang yang berprestasi mempunyai pengaruh yang besar dalam promosi jabatan

4. Kesempatan Promosi Jabatan di organisasi harus memperhatikan kesesuaian dengan latar belakang prendidikan sesuai dengan kesempatan dalam jabatan

\subsubsection{Tujuan dan Manfaat Promosi Jabatan}

Promosi jabatan merupakan kenaikan jabatan yang lebih tinggi, sehingga dalam promosi jabatan memiliki tujuan dan manfaat terhadap organisasi. Menurut Hasibuan, bahwa tujuan promosi adalah sebagai berikut:

1) Untuk memberikan pengakuan, jabatan, imbalan, dan imbalan jasa yang semakin besar kepada karyawan yang memiliki prestasi tinggi.

2) Dapat menimbulkan kepuasan dan kebanggaan pribadi, status sosial yang semakin tinggi, penghasilan yang besar.

3) Untuk merangsang agar karyawan lebih bergairah dalam bekerja, disiplin tinggi, dan memperbesar produktivitas kerjanya..

4) Kesempatan promosi dapat menimbulkan keuntungan berantai dalam perusahaan karena timbulnya lowongan berantai.

5) Memberikan kesempatan kepada karyawan untuk mengembangkan kreativitas dan inovasinya yang lebih baik demi keuntungan optimal perusahaan.

6) Untuk menambah atau memperluas pengetahuan serta pengalaman kerja para karyawan dan ini merupakan daya dorong untuk karyawan lainnya.

7) Karyawan yang dipromosikan jabatan kepada jabatan yang lebih tepat, semangat, kesenangannya dalam bekerja semakin meningkat, sehingga produktivitas bekerjanya semakin meninggkat.

8) Untuk mempermudah penarikan pelamar, sebab dengan adanya kesempatan promosi merupakan daya dorong serat perangsang bagi pelamar untuk memasukan lamarannya.

9) Promosi jabatan memungkinkan perusahaan untuk mendayagunakan keahlihan dan kemapuan karyawan setinggi mungkin.

10) Promosi dapat memungkinkan perusahaan memanfaatkan

kemampuan karyawan untuk memperluas usahanya.

\subsection{Indikator Promosi Jabatan}

Untuk melakukan promosi jabatan, maka organisasi perlu mengetahui tolak ukur dalam melakukan promosi jabatan. Menurut Hasibuan, bahwa promosi untuk setiap perusahaan tidak selalu sama tergantung kepada perusahaan masingmasing.

Syarat-syarat atau indikator pada umumnya sebagai berikut :

- Prestasi kerja Karyawan

- mampu mencapai hasil kerja yang dapat dipertanggung jawabkan

- kualitas maupun kuantitas dan

- bekerja secara efektif dan efisien.

Hal ini menunjukan bahwa karyawan dapat memanfaatkan waktu dan mempergunakan alat-alat dengan baik. Pegawai yang memenuhi prestasi yang memenuhi syarat akan dipromosikan kejenjang jabatan yang lebih tinggi dari sebelumnya. Kerjasama Karyawan dapat bekerja sama secara harmonis dengan sesama karyawan baik horizontal maupun vertikal dalam mencapai sasaran perusahaan. Dengan demikian akan tercipta suasan hubungan baik diantara semua karyawan Kecakapan Karyawan harus cakap, aktif, kreatif, dan enovatif dalam menyelsaikan tugas-tugas pada jabatan tersebut dengan baik. Karyawan mampu bekerja mandiri dalam menyelesaikan pekrjaanya dengan baik tanpa mendapatkan bimbingan secara terus menerus dari atasannya.

Adapun menurut Nitisemito beberapa indikator dalam penetapan promosi jabatan sebagai berikut :

1. Pengalaman (senioritas)

Banyaknya pengalaman seorang karyawan seringkali digunakan sebagai salah satu syarat untuk promosi, karena 
dengan adanya pengalaman yang lebih banyak, maka karyawan diharapkan untuk mempu bekerja yang tinggi dengan ide yang lebih banyak. Pengalaman menjadi prioritas dalam pertama dalam tindakan promos

2. Tingkat pendidikan

Ada sebagian perusahaan memberikan syarat minimal pendidikan agar dapat di promosikan pada jabatan tertentu. Hal ini mempunyai alasan bahwa dengan pendidikan yang lebih tinggi, maka dapat di harapkan karyawan yang memiliki jalan pemikiran yang lebih baik. Spesialis pendidikan merupakan keahlian yang dimiliki seorang pegawai sehingga dapat lebih mudah dalam melaksanakan tugas yang menjadi tanggung jawab.

\subsection{Penelitian terdahulu}

Untuk mengadakan penelitian, tidak terlepas dari penelitian yang dilakukan oleh peneliti terdahulu dengan tujuan untuk memperkuat hasil dari penelitian yang sedang dilakukan, selain itu juga bertujuan untuk membandingkan dengan penelitian yang dilakukan sebelumnya. Berikut ringkasan hasil penelitian terdahulu yang dilakukan oleh peneliti selama melakukan penelitian

Tabel -1

Ringkasan Hasil Penelitian Terdahulu

\begin{tabular}{|c|c|c|c|c|c|}
\hline No. & Peneliti & Judul & Variabel & Hasil & $\begin{array}{c}\text { Alat } \\
\text { Analisis }\end{array}$ \\
\hline 1. & $\begin{array}{l}\text { Angga } \\
\text { Harisma } \\
(2015)\end{array}$ & $\begin{array}{l}\text { Pengaruh penilaian } \\
\text { prestasi kerja dan lo } \\
\text { yalitas karyawan terha } \\
\text { dap promosi jabatan } \\
\text { pada P.T Sanbe Farma } \\
\text { Cimareme. }\end{array}$ & $\begin{array}{l}\text { Variabel bebas: } \\
\text { Perstasi kerja } \\
\text { (X1) } \\
\text { Variabel terikat: } \\
\text { Promosi Jabatan } \\
\text { (Y) }\end{array}$ & $\begin{array}{l}\text { Dari hasil ouput SPSS } \\
\text { di dapatkan nilai } \\
\text { koefisien korelasi di } \\
\text { atas dapat dilihat } \\
\text { bahwa hubungan pe } \\
\text { nilaian prestasi }\left(\mathrm{X}_{1}\right) \\
\text { dengan loyalitas }\left(\mathrm{X}_{2}\right) \\
\text { sebesar 0,487 dan } \\
\text { masuk dalam kate } \\
\text { gori sedang. Arah } \\
\text { hubungan positif } \\
\text { dengan loyalitas me } \\
\text { nunjukan bahwa pe } \\
\text { nilaian prestasi kerja } \\
\text { yang makin tinggi } \\
\text { diikuti dengan me } \\
\text { ningkatkan loyalitas. }\end{array}$ & $\begin{array}{l}\text { Regresi } \\
\text { Linier } \\
\text { sederhana }\end{array}$ \\
\hline 2. & $\begin{array}{l}\text { Yulia Banyu } \\
\text { Rani (2017) }\end{array}$ & $\begin{array}{l}\text { Pengaruh pelaksanaan } \\
\text { penilaian prestasi } \\
\text { kerja karyawan } \\
\text { terhadap promosi } \\
\text { jabatan pada PT.KK } \\
\text { Indonesiall. }\end{array}$ & $\begin{array}{l}\text { Pengaruh } \\
\text { pelaksanaan } \\
\text { penilaian prestasi } \\
\text { kerja karyawan } \\
\text { terhadap promosi } \\
\text { jabatan pada } \\
\text { PT.KK } \\
\text { Indonesiall. }\end{array}$ & $\begin{array}{l}\text { Penelitian ini menya } \\
\text { takan bahwa semua } \\
\text { item intrumaen dinya } \\
\text { takan valid, karena } \\
\text { nilai r sebesar } 0,361 \\
\text { dengan jumlah res } \\
\text { ponden } 100 \text { orang. } \\
\text { Promosi jabatan me } \\
\text { miliki hubungan yang } \\
\text { tinggi atau kuat ter } \\
\text { hadap promosi jaba } \\
\text { tan sebesar } 0,710\end{array}$ & $\begin{array}{l}\text { Regresi } \\
\text { Linier } \\
\text { sederhana }\end{array}$ \\
\hline
\end{tabular}

\subsection{Kerangka Pemikiran}

Konsep Kerangka pemikiran adalah istilah dan defenisi yang digunakan untuk menggambarkan secara abstrak mengenai kejadian, keadaan, kelompok atau individu yang menjadi perhatian ilmu sosial. Menurut Singarimbun (2001:33), konsep adalah abstraksi mengenai suatu fenomena yang dirumuskan atas dasar generalisasi. Untuk mendapatkan 
batasan-batasan yang lebih jelas mengenai variabel-variabel yang akan diteliti, maka defenisi konsep yang digunakan dalam pengertian ini adalah :

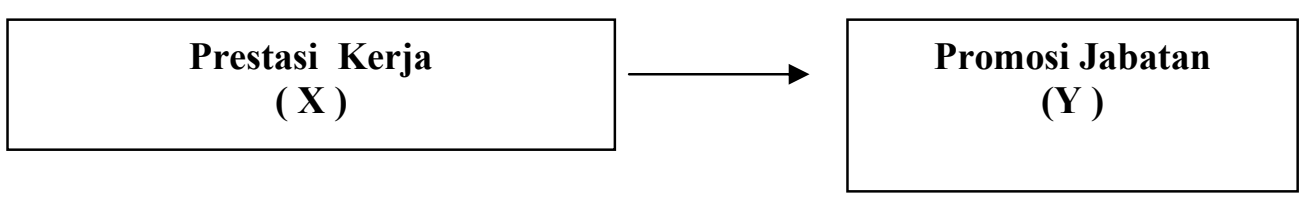

Gambar-1

Desain penelitian ini menjelaskan hubungan antara variabel (X) dengan variabel (Y), dimana pengaruh penilaian prestasi kerja sebagai variabel bebas (X) sangat berpengaruh terhadap promosi jawaban sebagai variabel terikat (Y).

\subsection{Hipotesis}

Hipotesisi penelitian ini adalah penilaian prestasi kerja Sangat Berpengaruh secara Signifikan Terhadap promosi jabatan karyawan Pada Dinas Perhubungan Sumatera Selatan.

\section{METODE PENELITIAN}

\subsection{Lokasi Penelitian}

Penelitian ini dilakukan Pada Kantor Dinas Perhubungan Kota Palembang yang beralamat di Jln Pangeran Sido Ing Lautan 35 ilir Palembang.

\subsection{Ruang Lingkup Penelitian}

Ruang linkup penelitian ini dibatasi dengan Pengaruh Penilaian Prestasi Kerja Terhadap Promosi Jabatan Pada Dinas Perhubungan Sumatera Selatan yang akan dilakukan dalam penelitian

\subsection{Desain Penelitian}

Desain penelitian merupakan pedoman yang digunakan dalam proses penelitian, oleh karena itu perlu disusun desain penelitian yang sistematis untuk menentukan langkah-langka Pengaruh Penilaian Prestasi Kerja Terhadap Promosi Jabatan Pada Dinas Perhubungan Sumatera Selatan yang akan dilakukan dalam penelitian. Objek dari penelitian ini adalah

Untuk jenis penelitian, yang dipergunakan adalah jenis peneltian studi kasus (case study). Studi kasus adalah jenis penelitian yang dilakukan secara intensif terinci dan mendalam atas suatu proyek penelitian dalam suatu fase spesifik dari keseluruhan personalitas. Penulis menggunakan jenis penelitian ini dengan alasan bahwa setiap perusahaan mempunyai suatu keadaan atau kondisi yang berbedabeda, hal ini disebabkan adanya nperbedaan besar kecilnya perusahaan dan jenis perusahaan. Pengertian studi kasus dijelaskan oleh Djahidin (2013:66) sebagai berikut : "Studi kasus adalah peneltian tentang status obyek penelitian yang berkenan dengan fase spesifik atau khas dari keeluruhan personalitas. Subyek penelitian dapat saja individu, kelompok, lembaga ataupun masyarakat".

\subsection{Jenis dan Sumber Data}

\subsubsection{Data Primer}

Data Primer yaitu data yang secara langsung berhubungan dengan responden yang diteliti dari sumbenya.

\subsubsection{Data Sekunder}

Data sekunder adalah data yang secara tidak langsung berhubungan dengan responden yang diteliti dan merupakan data pendukung bagi peneliti yang dilakukan. Data sekunder ini biasanya merupakan catatancatatan yang ada pada perusahaan yang pengumpulannya tidak dilakukan sendiri oleh peneliti.. 


\subsection{Populasi dan Sampel}

Pada penelitian ini, populasi adalah karyawan yang bekerja pada Dinas Perhubungan Kota Palembang.

Sampel adalah bagian dari jumlah dan karakteristik yang dimiliki oleh populasi tersebut. Sugiyono (2010:116). Adapun penentuan jumlah sampel pada penelitian ini adalah menggunakan teknik probabilitas dengan cara random sampling (Metode sampel acak sederhana), yaitu dengan metode pemilihan sampel di mana setiap anggota populasi mempunyai peluang yang sama untuk dipilih menjadi anggota sampel.

Untuk menentukan jumlah sampel yang diambil pada penelitian ini menggunakan rumus slovin :

Dimana: $\mathrm{n}$ = banyaknya sampel

$$
\mathrm{n}=\frac{n}{N e^{2}+1}
$$

$\mathrm{N}$ = banyaknya sampel

$\mathrm{e}^{2}=$ persen kelonggaran ketidaktelitian karena kesalahan pengambilan sampel yang masih dapat ditolerir, yaitu 0,1 atau $10 \%$.

Pada penelitian ini yang bertempat pada Dinas Perhubungan Sumatera Selatan Memiliki karyawan /pekerja sebanyak 311 orang.

$$
\begin{aligned}
& \mathrm{n}=\frac{311}{311 \times 0,1^{2}+1} \\
& =\quad 311 \\
& 3,1+1 \\
& =\quad 75,85 \text { atau } 76 \text { Orang }
\end{aligned}
$$

Berdasarkan hasil perhitungan di atas maka penulis menggenapkan jumlah sampel menjadi 76 sampel.

\subsection{Teknik Analisis Data}

a. Uji Validitas dan Reabilitas

Pada setiap pengukuran selalu diharapkan diperoleh hasil ukur yang akurat dan objektif. Salah satu upaya untuk mencapainya adalah alat ukur yang digunakan harus valid atau sahih dan reliabel atau andal (Simamora, Bilson : 2002: 58). Uji validitas digunakan untuk mendapatkan validitas yang tinggi dari instrumen penelitian sehingga bisa memenuhi persyaratan. Sedangkan uji reliabilitas dilakukan guna memperoleh gambaran yang tetap mengenai apa yang diukur. Uji validitas dan reabilitas ini dengan menggunakan koefisien korelasi Pearson Product Moment yang diperoleh melalui analisa data. Item yang memiliki daya beda cukup tinggi akan dihitung reliabilitasnya dengan menggunakan reliabilitas koefisien alpha yang diperoleh melalui analisis data . Itemitem dalam skala yang memiliki validitas yang baik dan reliabel akan digunakan untuk mengukur.

\section{b. Analisis Regresi linier Sederhana}

Regresi Linear Sederhana adalah Metode Statistik yang berfungsi untuk menguji sejauh mana hubungan sebab akibat antara Variabel Faktor Penyebab (X) terhadap Variabel Akibatnya. Faktor Penyebab pada umumnya dilambangkan dengan $\mathrm{X}$ atau disebut juga dengan Predictor sedangkan Variabel Akibat dilambangkan dengan $\mathrm{Y}$ atau disebut juga dengan Response. Regresi Linear 
Sederhana atau sering disingkat dengan SLR (Simple Linear Regression) juga merupakan salah satu Metode Statistik yang dipergunakan dalam produksi untuk melakukan peramalan ataupun prediksi tentang karakteristik kualitas maupun Kuantitas. Model Persamaan Regresi Linear Sederhana adalah seperti berikut ini :

$$
\mathbf{Y}=\mathbf{a}+\mathbf{b X}
$$

Dimana :

$\mathrm{Y}=$ Variabel Penilaian Prestasi Kerja

(Dependent)

$\mathrm{X}=$ Variabel Promosi Jabatan

(Independent)

$\mathrm{a}=$ konstanta

$\mathrm{b}=$ koefisien regresi (kemiringan); besaran Response yang ditimbulkan oleh Predictor.

Nilai-nilai a dan b dapat dihitung dengan menggunakan Rumus dibawah ini :

$$
\begin{array}{lc}
\mathrm{a}= & \frac{(\Sigma \mathrm{y})\left(\sum \mathrm{x}^{2}\right)-(\Sigma \mathrm{x})(\Sigma \mathrm{xy})}{\mathrm{n}\left(\Sigma \mathrm{x}^{2}\right)-(\Sigma \mathrm{x})^{2}} \\
\dot{\mathrm{b}}=\frac{\mathrm{n}(\Sigma \mathrm{xy})-(\Sigma \mathrm{x})(\Sigma \mathrm{y})}{\mathrm{n}\left(\Sigma \mathrm{x}^{2}\right)-(\Sigma \mathrm{x})^{2}}
\end{array}
$$

Data yang diperoleh nantinya akan diolah menggunakan program olah data komputer yaitu SPSS 19.0.0 untuk menghasilakan nilai koefisien determinasi yang lebih akurat.

\subsection{Uji Hipotesis}

- Uji F

Uji $F$ digunakan untuk mengetahui pengaruh secara bersamasama variabel independen terhadap variabel dependen.

- Jika Fhitung $<$ Ftabel, maka independen tidak berpengaruh signifikan terhadap variabel dependen.

- Jika Fhitung $>$ Ftabel, maka independen mempunyai hubungan yang signifikan terhadap variabel dependen.

\section{- Uji T}

Menurut Sugiono (2010:366), uji $\mathrm{T}$ digunakan untuk menguji sendirisendiri secara signifikan hubungan antara variabel independen (variabel X) dengan variabel dependen (variabel Y).

- Jika thitung $>$ tabel maka variabel independen mempunyai keeratan hubungan yang signifikan terhadap variabel dependen.

- Jika thitung $<$ tabel maka variabel independen tidak mempunyai keeratan hubungan yang signifikan.

\section{HASIL PENELITIAN DAN \\ PEMBAHASAN}

\subsubsection{Profil Responden}

Responden dalam penelitian ini adalah karyawan populasinya berjumlah 311 karyawan. Dari jumlah tersebut sampel yang diambil sebesar 76 karyawan.

\subsubsection{Responden menurut Tingkat Pendidikan}

Tingkat pendidikan terakhir sangat mempengaruhi kemampuan dan tingkat kepercayaan diri seorang karyawan dalam melakukan pekerjaannya. Karyawan dengan pendidikan yang tinggi akan lebih mampu menyelesaikan pekerjaan dengan tingkat kesulitan yang lebih tinggi daripada karyawan dengan tingkat pendidikan yang lebih rendah. Tanggung jawab dari karyawan dengan tingkat pendidikan yang tinggi biasanya juga jauh lebih tinggi karena mereka lebih dipercaya untuk menangani tingkat pekerjaan yang dianggap tidak mampu dikerjakan oleh karyawan yang kurang pengalaman, apalagi yang berpendidikan tidak terlalu tinggi. Data mengenai responden menurut tingkat pendidikan dapat dilihat pada tabel -2 berikut ini 
Tabel -2

Tingkat Pendidikan Responden

Dinas Perhubungan Sumatera Selatan

\begin{tabular}{|c|c|c|}
\hline Tingkat Pendidikan & Jumlah & Persentase \% \\
\hline SMA & 39 & 51,32 \\
\hline D3 & 21 & 27,63 \\
\hline S1 & 16 & 21,05 \\
\hline Jumlah & $\mathbf{7 6}$ & $\mathbf{1 0 0 \%}$ \\
\hline
\end{tabular}

Sumber : Dinas Perhubungan Kota Palembang

Dari tabel-2 dapat dilihat bahwa tingkat pendidikan sebagian besar karyawan pada kantor Dinas Perhubungan Sumatera Selatan menjadi responden dalam penelitian ini adalah SMA yaitu berjumlah 29 orang atau 48\%. Kemudian S1 berjumlah 10 orang atau $17 \%$ dan Diploma berjumlah 21 Orang atau 35\%.

\subsubsection{Responden Menurut usia}

Usia seorang pegawai sangat menentukan kinerja secara keseluruhan. Pegawai dengan usia relatif masih muda akan mempunyai kemampuan fisik yang lebih baik daripada karyawan yang lebih tua. Akan tetapi seorang karyawan yang sudah berusia lebih tua akan mempunyai pengalaman yang tidak dimilikin oleh karyawan yang masih berusia muda. Oleh karena itu akan lebih baik apabila perusahaan menggabungkan atau memadukan karyawan berusia tua dengan usia muda.

Data mengenai responden menurut umur dapat dilihat pada tabel -3 berikut ini

Tabel -3

Tingkat Usia Responden

Dinas Perhubungan Sumatera Selatan.

\begin{tabular}{|c|c|c|}
\hline Tingkat Pendidikan & Jumlah & Persentase \% \\
\hline$<20$ Tahun & 10 & 13,16 \\
\hline 21-30 Tahun & 15 & 19,74 \\
\hline 31-40 Tahun & 35 & 46,05 \\
\hline 41-50 Tahun & 16 & 21,05 \\
\hline & $\mathbf{7 6}$ & $\mathbf{1 0 0 \%}$ \\
\hline
\end{tabular}

Sumber : Dinas Perhubungan Kot a Palembang

Dari Tabel-3 dapat dilihat bahwa sebagian besar karyawan Dinas Perhubungan Sumatera Selatan yang menjadi responden dalam penelitian ini adalah berusia sekitar 31-40 tahun yaitu berjumlah 35 orang atau 46,05\%, karyawan yang berusia 21-30 tahun berjumlah 15 orang atau 19,74\%, karyawan yang berusia 41-50 tahun berjumlah 16 orang atau $21,05 \%$ yang paling sedikit adalah karyawan yang berusia 20 tahun yang berjumlah 10 orang atau $13,16 \%$.

\subsubsection{Responden Menurut Masa Kerja}

Tabel -4

Tingkat Masa Kerja Responden

Dinas Perhubungan Sumatera Selatan

\begin{tabular}{|c|c|c|}
\hline Tingkat Pendidikan & Jumlah & Persentase \% \\
\hline Tahun & 36 & 47,37 \\
\hline 6-10 Tahun & 12 & 15,79 \\
\hline
\end{tabular}




\begin{tabular}{|rl|r|r|}
\hline $11-15$ & Tahun & 19 & 25,00 \\
\hline $16-20$ & Tahun & 9 & 11,84 \\
\hline & & $\mathbf{7 6}$ & $\mathbf{1 0 0 \%}$ \\
\hline
\end{tabular}

Sumber : Dinas Perhubungan Kota palembang

Dari Tabel-4 dapat dilihat bahwa masa kerja sebagian besar karyawan yang menjadi responden dalam penelitian ini adalah 36 orang atau sebesar 47,37\%, karyawan yang bekerja antara 6-10 tahun berjumlah 12 orang atau $15,79 \%$ dan $11-15$ tahun adalah masing-masing 19 orang atau 25\% karyawan yang masa kerja berkisar 16-20 tahun sebanyak 9 orang atau $11,84 \%$.

\subsection{Rekapitulasi jawaban responden}

\subsubsection{Variabel Penilaian Prestasi Kerja (X)}

- Karyawan selalu berusaha meningkatkan pengetahuan dan keterampilan sesuai dengan bidang pekerjaannya

\begin{tabular}{|l|c|c|}
\hline \multirow{2}{*}{\multicolumn{1}{|c|}{ Pernyataan }} & \multicolumn{2}{c|}{ Rasponden } \\
\cline { 2 - 3 } & Frekuensi & \% \\
\hline Sangat Setuju & 59 & 77,63 \\
\hline Setuju & 16 & 21,05 \\
\hline Kurang Setuju & 1 & 1,32 \\
\hline Tidak Setuju & 0 & 0 \\
\hline Sangat Tidak Setuju & 0 & 0 \\
\hline \multicolumn{1}{|c|}{ Jumlah } & $\mathbf{7 6}$ & $\mathbf{1 0 0}$ \\
\hline
\end{tabular}

Sumber ; Diolah dari hasil penelitian 2020

Hasil responden Proses rekrutmen yang dilakukan oleh adalah sebanyak 59 responden atau 77,63\% menyatakan sangat setuju dan 16 responden atau $21,05 \%$ menyatakan setuju serta sisanya menyatakan kurang setuju. Dari perhitungan responden diatas dapatlah kita katakan bahwa variabel ini sangat baik.

- Karyawan berusaha menyelesaikan pekerjaan sesuai dengan kuantitas yang telah ditetapkan perusahaan

\begin{tabular}{|l|c|c|}
\hline \multirow{2}{*}{\multicolumn{1}{c|}{ Pernyataan }} & \multicolumn{2}{c|}{ Rasponden } \\
\cline { 2 - 3 } & Frekuensi & \% \\
\hline Sangat Setuju & 41 & 53,94 \\
\hline Setuju & 33 & 43,42 \\
\hline Kurang Setuju & 2 & 2,64 \\
\hline Tidak Setuju & 0 & 0 \\
\hline Sangat Tidak Setuju & 0 & 0 \\
\hline \multicolumn{1}{|c|}{ Jumlah } & $\mathbf{7 6}$ & $\mathbf{1 0 0}$ \\
\hline
\end{tabular}

Sumber; Diolah dari hasil penelitian 2020

Hasil responden yang dilakukan oleh Dinas Perhubungan Sumatera Selatan. adalah sebanyak 41 responden atau 53,94\% menyatakan sangat setuju dan 33 responden atau $43,42 \%$ menyatakan setuju serta sisanya menyatakan kurang setuju. Dari perhitungan responden diatas dapatlah kita katakan bahwa variabel ini sangat baik.

- Karyawan selalu menyelesaikan tugas-tugas dengan tepat waktu dan mengutamakan prinsip efisiensi 


\begin{tabular}{|l|c|c|}
\hline \multirow{2}{*}{\multicolumn{1}{c|}{ Pernyataan }} & \multicolumn{2}{c|}{ Rasponden } \\
\cline { 2 - 3 } & Frekuensi & \% \\
\hline Sangat Setuju & 49 & 64,47 \\
\hline Setuju & 25 & 32,89 \\
\hline Kurang Setuju & 2 & 2,64 \\
\hline Tidak Setuju & 0 & 0 \\
\hline Sangat Tidak Setuju & 0 & 0 \\
\hline \multicolumn{1}{|c|}{ Jumlah } & $\mathbf{7 6}$ & $\mathbf{1 0 0}$ \\
\hline
\end{tabular}

Hasil responden yang dilakukan Dinas Perhubungan Sumatera Selatan. adalah sebanyak 49 responden atau $64,47 \%$ menyatakan sangat setuju dan 25 responden atau $32,89 \%$ menyatakan setuju serta sisanya menyatakan kurang setuju. Dari perhitungan responden diatas dapatlah kita katakan bahwa variabel ini sangat baik.

- Pengetahuan yang karyawan miliki sesuai dengan standar perusahaan

\begin{tabular}{|l|c|c|}
\hline \multirow{2}{*}{\multicolumn{1}{c|}{ Pernyataan }} & \multicolumn{2}{c|}{ Rasponden } \\
\cline { 2 - 3 } Sangat Setuju & Frekuensi & \% \\
\hline Setuju & 42 & 56,57 \\
\hline Kurang Setuju & 26 & 34,21 \\
\hline Tidak Setuju & 8 & 10,52 \\
\hline Sangat Tidak Setuju & 0 & 0 \\
\hline \multicolumn{1}{|c|}{ Jumlah } & $\mathbf{7 6}$ & $\mathbf{1 0 0}$ \\
\hline
\end{tabular}

\section{Sumber : Diolah dari hasil penelitian 2020}

Hasil responden yang dilakukan oleh kantor Dinas Perhubungan Propinsi Sumatera Selatan adalah sebanyak 42 responden atau 56,57\% menyatakan sangat setuju dan 26 responden atau 34,21\% menyatakan setuju serta sisanya menyatakan kurang setuju. Dari perhitungan responden diatas dapatlah kita katakan bahwa variabel ini sangat baik.

- Karyawan datang tepat waktu

\begin{tabular}{|l|c|c|}
\hline \multirow{2}{*}{\multicolumn{1}{|c|}{ Pernyataan }} & \multicolumn{2}{c|}{ Rasponden } \\
\cline { 2 - 3 } Sangat Setuju & Frekuensi & \% \\
\hline Setuju & 38 & 50,00 \\
\hline Kurang Setuju & 2 & 47,37 \\
\hline Tidak Setuju & 0 & 2,63 \\
\hline Sangat Tidak Setuju & 0 & 0 \\
\hline \multicolumn{1}{|c|}{ Jumlah } & $\mathbf{7 6}$ & 0 \\
\hline
\end{tabular}

\section{Sumber : Diolah dari hasil penelitian 2020}

Hasil responden yang dilakukan oleh kantor Dinas Perhubungan Propinsi Sumatera Selatan adalah sebanyak 38 responden atau 50\% menyatakan sangat setuju dan 36 responden atau 47,37\% menyatakan setuju serta sisanya menyatakan kurang setuju. Dari perhitungan responden diatas dapatlah kita katakan b Bahwa variabel ini sangat baik 
VARIABEL PROMOSI JABATAN (VARIABEL Y)

- Perusahaan menempatkan jabatan sesuai dengan latar belakang pendidikan

\begin{tabular}{|c|c|c|}
\hline \multirow{2}{*}{ Pernyataan } & \multicolumn{2}{|c|}{ Rasponden } \\
\cline { 2 - 3 } & Frekuensi & $\%$ \\
\hline Sangat Setuju & 48 & 63,15 \\
\hline Setuju & 26 & 34,21 \\
\hline Kurang Setuju & 2 & 2,63 \\
\hline Tidak Setuju & 0 & 0 \\
\hline Sangat Tidak Setuju & 0 & 0 \\
\hline Jumlah & $\mathbf{7 6}$ & $\mathbf{1 0 0}$ \\
\hline
\end{tabular}

Sumber : Diolah dari hasil penelitian 2020

Hasil responden yang dilakukan oleh kantor Dinas Perhubungan Propinsi Sumatera Selatan adalah sebanyak 48 responden atau 63,15\% menyatakan sangat setuju dan 26 responden atau 34,21\% menyatakan setuju serta sisanya menyatakan kurang setuju. Dari perhitungan responden diatas dapatlah kita katakan bahwa variabel ini sangat baik.

- Masa kerja menjadi pertimbangan dalam promosi jabatan atau kenaikan golongan

\begin{tabular}{|c|c|c|}
\hline \multirow{2}{*}{ Pernyataan } & \multicolumn{2}{|c|}{ Rasponden } \\
\cline { 2 - 3 } Sangat Setuju & Frekuensi & \% \\
\hline Setuju & 39 & 51,32 \\
\hline Kurang Setuju & 36 & 47,37 \\
\hline Tidak Setuju & 1 & 1,31 \\
\hline Sangat Tidak Setuju & 0 & 0 \\
\hline Jumlah & $\mathbf{7 6}$ & 0 \\
\hline
\end{tabular}

Sumber : Diolah dari hasil penelitian 2020

Hasil responden yang dilakukan oleh kantor Dinas Perhubungan Propinsi Sumatera Selatan adalah sebanyak 39 responden atau 51,32\% menyatakan sangat setuju dan 36 responden atau 47,37\% menyatakan setuju serta sisanya menyatakan kurang setuju. Dari perhitungan responden diatas dapatlah kita katakan bahwa variabel ini sangat baik.

- Semakin banyaknya pengalaman maka perusahaan akan mempromosikan pegawai tersebut

\begin{tabular}{|c|c|c|}
\hline \multirow{2}{*}{ Pernyataan } & \multicolumn{2}{|c|}{ Rasponden } \\
\cline { 2 - 3 } & Frekuensi & \% \\
\hline Sangat Setuju & 43 & 56,58 \\
\hline Setuju & 29 & 38,16 \\
\hline Kurang Setuju & 4 & 5,26 \\
\hline Tidak Setuju & 0 & 0 \\
\hline Sangat Tidak Setuju & 0 & 0 \\
\hline Jumlah & $\mathbf{7 6}$ & $\mathbf{1 0 0}$ \\
\hline
\end{tabular}

Sumber : Diolah dari hasil penelitian 2020

Hasil responden yang dilakukan kantor Dinas Perhubungan Propinsi Sumatera Selatan adalah sebanyak 43 responden atau 56,58\% menyatakan sangat setuju dan 29 responden atau $38,16 \%$ menyatakan setuju serta sisanya 
menyatakan kurang setuju. Dari perhitungan responden diatas dapatlah kita katakan bahwa variabel ini sangat baik.

- Sering berpartisipasi mempunyai nilai tersendiri

\begin{tabular}{|c|c|c|}
\hline \multirow{2}{*}{ Pernyataan } & \multicolumn{2}{|c|}{ Rasponden } \\
\cline { 2 - 3 } Sangat Setuju & Frekuensi & $\%$ \\
\hline Setuju & 48 & 63,16 \\
\hline Kurang Setuju & 27 & 35,53 \\
\hline Tidak Setuju & 1 & 1,31 \\
\hline Sangat Tidak Setuju & 0 & 0 \\
\hline Jumlah & $\mathbf{7 6}$ & 0 \\
\hline
\end{tabular}

Sumber : Diolah dari hasil penelitian 2020

Hasil responden yang dilakukan oleh kantor Dinas Perhubungan Propinsi Sumatera Selatan adalah sebanyak 48 responden atau 63,16\% menyatakan sangat setuju dan 27 responden atau 35,53\% menyatakan setuju serta sisanya menyatakan kurang setuju. Dari perhitungan responden diatas dapatlah kita katakan bahwa variabel ini sangat baik.

\section{Uji Statistik/Analisis Data}

\subsubsection{Uji Instrumen}

- Validasi Data

Menurut Sugiyono (2018:445), instrumen yang valid berarti alat ukur yamg digunakan untuk mendapatkan data (mengukur) itu valid. Teknik yang digunakan untuk mengukur validitas bulir pertanyaan kuisiner adalah correlasion product moment dari Karl Pearson ( Validitas isi / content validity ) dengan cara mengkorelasikan masingmasung item pertanyaan kuesioner dan totalnya, selanjutnya membandingkan $r$ tabel dan $r$ hitung. Pengujian validitas dari penelitian ini dilakukan dengan menggunakan aplikasi sofware SPSS Ver 22,0, jika total (corrected item total corelation) $=0,30$ jadi apabila $\mathrm{r}$ positif 0,3 maka tidak valid.

Validasi data variabel Penilaian Presatasi Kerja dan Promosi Jabatan (Y)

Tabel 4.7.1

Hasil Uji Validitas

\begin{tabular}{|c|c|c|c|}
\hline Variabel & $\begin{array}{c}\text { Butir } \\
\text { Pertanyaan }\end{array}$ & $\begin{array}{c}\text { Corrected item total } \\
\text { correlation }\end{array}$ & Status \\
\hline \multirow{3}{*}{$\begin{array}{c}\text { Penilaian } \\
\text { Prestasi Kerja } \\
(X)\end{array}$} & $\mathrm{X} 1$ & 0,461 & Valid \\
\cline { 2 - 4 } & $\mathrm{X} 2$ & 0,725 & Valid \\
\cline { 2 - 4 } & $\mathrm{X} 4$ & $\mathbf{0 , 7 8 8}$ & Valid \\
\hline \multirow{2}{*}{$\begin{array}{c}\text { Promosi } \\
\text { Jabatan } \\
(Y)\end{array}$} & $\mathrm{X} 1.1$ & 0,588 & Valid \\
\cline { 2 - 4 } & $\mathrm{X} 1.2$ & 0,444 & Valid \\
\cline { 2 - 4 } & $\mathrm{X} 1.3$ & 0,619 & Valid \\
\hline
\end{tabular}

Sumber : Data diolah 2019

Pada tabel 4.7.1 yang menunjukan validasi data penelitian pada variabel bebas dan terikat dapat hasil sebagai berikut : 
- $\quad$ Pada variabel Penilaian preastasi kerja (X) bahwa seluruh item dari (5 butir) dinyatakan valid karena Corrected item total correlation menunjukan lebih besar dari $>0,30$

- $\quad$ Sedangkan pada variabel Promosi jabatan (Y) bahwa seluruh item dari (4 butir) dinyatakan valid karena Corrected item total correlation menunjukan lebih besar dari $>0,30$

\section{- Reliabilitas}

Uji reliilitas dilakukan untuk mengukur tingkat konsistensi antara hasil pengamatan dengan instrumen atau alat ukur yang digunakan pada waktu yang berbrda. Ghozali dalam situmorang (2018: 112) menyatakan teknik yang digunakan untuk mengukur relialitas pengamatan adalah Cronbach Alpha dengan cara membandingkan nilai alpha dengan standarnya, dengan ketentuan :

1. Cronbach Alpha $>0,6$ maka instrumen pengamatan dinyatakan reliabel
2. Cronbach Alpha $<0,6$ maka instrumen pengamatan tidak reliabel

- Reabilitas Variabel Penilaian prestasi $\operatorname{kerja}(\mathrm{X})$

Hasil perhitungan nilai reliabilitas Cronbach Alpa untuk variabel pendidikan dengan bantuan SPSS 22,0 adalahsebesar 0,788. Artinya dari 5 item pernyataan yang dijadikan sebagai indikator pada variabel pendidikan $\left(\mathrm{X}_{1}\right)$ sudah realibel.

- Reabilitas Prestasi kerja karyawan (Y)

Hasil perhitungan nilai reliabilitas Cronbach Alpa untuk variabel prestasi kerja karyawan dengan bantuan SPSS 22,0 adalah sebesar 0,702. Artinya dari 4 item pernyataan yang dijadikan sebagai indikator pada variabel prestasi kerja karyawan (Y) sudah realibel. Hasil uji reabilitas secara lebih terperinci dapat dilihat pada tabel berikut ini :

Tabel 4.2.1

Hasil Uji Reliabilitas

\begin{tabular}{|c|c|c|}
\hline Variabel & Alfha Cronbach ( $\approx)$ & Status \\
\hline Penilaian Prestasi Kerja & 0,788 & Reliabilitas \\
\hline Promosi Jabatan & 0,702 & Reliabilitas \\
\hline
\end{tabular}

Tabel 4.2.2

Ringkasan Model

\begin{tabular}{|l|r|r|r|r|}
\hline Model & R & R Square & $\begin{array}{c}\text { Adjusted R } \\
\text { Square }\end{array}$ & $\begin{array}{c}\text { Std. Error of } \\
\text { the Estimate }\end{array}$ \\
\hline 1 &, $812^{\mathrm{a}}$ &, 659 &, 089 & 3,54803 \\
\hline
\end{tabular}

a. Predictors: (Constant), Penilaian Prestasi Kerja

Koefissien determinasi (R2) pada intinya mengukur seberapa jauh kemampuan model dalam menerangkan variasi variabel dependen. Nilai koefisien determinasi adalah nol atau satu. Nilai R2 = yang kecil bearti kemampuan variabel-variabel independen dalam menjelaskan variasi variabeldependen amat terbatas.

a. $\mathrm{R}$ dalam analisis regresi berganda menunjukan korelasi yaitu antara dua variabel independent terhadap satu variabel dependent. Angka $\mathrm{R}$ didapat 0 , artinya korelasi antara 
variabel pendidikan dan pelatihan sebesar 0,812 hal ini bearti terjadi hubungan yang kuat karena nilainya mendekati 1 .

b. $\mathrm{R}$ Square $\left(\mathrm{R}^{2}\right)$ yaitu menunjukan nilai koefisien determinasi. Angka ini akan di ubah ke bentuk persen yang artinya persentase sumbangan pengaruh variabel dependent. Nilai $\mathrm{R}^{2}$ sebesar 0,659 artinya sumbangan prndidikan dan pelatihan terhadap prestasi kerja karyawan sebesar $56,1 \%$ sedangkan sisanya dipengaruhi oleh variabel lain yang tidak dimasukkan dalam penelitian ini.

\section{- Uji Regresi linier sederhana}

Data yang diperoleh dari responden dalam penelitian ini dianalisis dengan menggunakan model regresi linier sederhana dengan tujuan untuk mengetahui besarnya kontribusi dari variabel-variabel bebas (independent) dalam peneitian ini yaitu penilaian prestasi kerja $(\mathrm{X})$ untuk memprediksi variabel promosi jabatan (Y) sebagai variabel terikat ( dependent ), sehimgga dapat dijelaskan pula mengenai variabel bebas yang paling berpengaruh terhadap variabel terikat nya. Pengelolaan data dilakukan dengan menggunakan program SPSS 22,0 dengan hasil sebagaimana terlihat pada tabel berikut

Tabel 4.8

Koefisien Regresi

Coefficients $^{\mathrm{a}}$

\begin{tabular}{|c|c|c|c|c|c|c|}
\hline \multirow{2}{*}{\multicolumn{2}{|c|}{ Model }} & \multicolumn{2}{|c|}{ Unstandardized Coefficients } & \multirow{2}{*}{$\begin{array}{c}\text { Standardized } \\
\text { Coefficients } \\
\text { Beta }\end{array}$} & \multirow[t]{2}{*}{$\mathrm{t}$} & \multirow[t]{2}{*}{ Sig. } \\
\hline & & B & Std. Error & & & \\
\hline \multirow[b]{2}{*}{1} & (Constant) & 13,736 & 6,932 & & 7,558 & ,000 \\
\hline & $\begin{array}{l}\text { Penilaian Prestasi } \\
\text { Kerja }\end{array}$ & ,250 & ,342 &, 060 & 3,248 & ,001 \\
\hline
\end{tabular}

a. Dependent Variable: Promosi Jabatan

c. Sumber : hasil olah data SPSS V 22,0

Tabel 4.2

Koefisien Regresi

Coefficients $^{\mathrm{a}}$

\begin{tabular}{|c|c|c|c|c|c|c|}
\hline \multirow{2}{*}{\multicolumn{2}{|c|}{ Model }} & \multicolumn{2}{|c|}{ Unstandardized Coefficients } & \multirow{2}{*}{$\begin{array}{c}\text { Standardized } \\
\text { Coefficients } \\
\text { Beta }\end{array}$} & \multirow[t]{2}{*}{$t$} & \multirow[t]{2}{*}{ Sig. } \\
\hline & & B & Std. Error & & & \\
\hline \multirow[b]{2}{*}{1} & (Constant) & 12,826 & 5,932 & & 7,668 &, 000 \\
\hline & $\begin{array}{l}\text { Penilaian Prestasi } \\
\text { Kerja }\end{array}$ & ,459 & ,267 &, 144 & 4,598 &, 000 \\
\hline
\end{tabular}

a. Dependent Variable: Promosi Jabatan

Sumber : hasil olah data SPSS V 22,0

Tabel 4.2 dapat dijelaskan sebagai berikut :

Kolom B menunjukan nilai-nilai koefisien regresi untuk konstanta dan masing-masing variabel bebas ( $\mathrm{X}_{1}$ dan $\mathrm{X}_{2}$ ) kolom (std. Error ) menunjukan nilai kesalahan baku untuk parameter kefisien regresi ,kolom ( beta ) menunjukan besarnya koefisien regresi yang di bakukan atau menunjukan koefsien jalur, kolom $(\mathrm{t}$ ) menunjukan nilai t-hitung untuk masing-masing parameter koefisien kolom ( sig ) menunjukan besarnya peluang kesalahan yang terjadi.

$$
\begin{array}{r}
\mathbf{Y}=\mathbf{a}+\mathbf{b x} \\
\mathrm{Y}=12,826+0,459 \mathrm{X}
\end{array}
$$


Dimana :

$\begin{array}{ll}\mathrm{Y} & =\text { Promosi Jabatan } \\ \mathrm{X} & =\text { Penilaian Prestasi Kerja } \\ a & =\text { konstanta } \\ b_{1} b_{2} & =\text { koefisien regresi }\end{array}$

Memperhatikan persamaan regresi linier berganda tersebut,diketahui nilai koefisien regresi dari masing-masing variabel bebas yang menunjukkan besarnya nilai yang disumbangkan oleh masing-masing variabel bebas terhadap variabel tidak bebasnya dengan asumsi variabel bebas lainnya dianggap konstan. Nilai koefisien yang mempunyai tanda positif berarti jika variabel bebas meningkat atau ditingkatkan,maka akan mendorong meningkatnya nilai dari variabel tidak bebas,demikian pula sebaliknya.

Penjelasan secara rinci dari masing-masing variabel adalah sebagai berikut:

a. Angka konstanta dari unstandardized coefficient yang dalam penelitian ini sebesar 12,826 angka ini berupa angka konstanta yang mempunyai arti : jika variabel penilaian prestasi kerja 0 ,maka jumlah promosi jabatan sebesar 12,826

b. Angka koefisien regresi $\mathrm{X}$ sebesar 0,459 . Angka tersebut mempunyai arti bahwa setiap penambahan $1 \%$ penilaian prestasi kerja maka promosi jabatan akan meningkat sebesar $0,459 \%$

c.

\section{Uji secara individu (Uji t)}

Uji $t$ menunjukkan seberapa besar pengaruh variabel bebas yang terdiri dari penilaian prestasi kerja (X) mempunyai pengaruh yang signifikan secara individu (parsial) terhadap promosi jabatan (Y). Dalam hal ini untuk mengetahui apakah secara parsial variabel penilaian prestasi kerja berpengaruh secara signifikan atau tidak terhadap promosi jabatan. Pengujian menggunakan tingkat signifikan 0,05.

Tabel 4.24

Coefficients $^{a}$

\begin{tabular}{|c|c|c|c|c|c|}
\hline \multirow[t]{2}{*}{ Model } & \multicolumn{2}{|c|}{ Unstandardized Coefficients } & \multirow{2}{*}{$\begin{array}{c}\begin{array}{c}\text { Standardized } \\
\text { Coefficients }\end{array} \\
\text { Beta }\end{array}$} & \multirow[t]{2}{*}{$\mathrm{T}$} & \multirow[t]{2}{*}{ Sig. } \\
\hline & $\mathrm{B}$ & Std. Error & & & \\
\hline (Constant) & 12,826 & 5,932 & & 7,668 & ,000 \\
\hline $\begin{array}{l}\text { Penilaian } \\
\text { prestasi Kerja }\end{array}$ & ,459 &, 267 &, 144 & 4,598 &, 000 \\
\hline
\end{tabular}

a. Dependent Variable: Promosi Jabatan

Pengujian variabel penilaian prestasi kerja (b1) dengan hipotesis :

$\mathrm{H} 0=$ koefisien regresi penilaian prestasi kerja secara parsial tidak berpengaruh terhadap promosi jabatan

$\mathrm{H} 1=$ koefisien regresi Penilaian prestasi kerja secara parsial berpengaruh terhadap promosi jabatan

Berdasarkan hasil dari output $\mathrm{t}$ hitung diperoleh sebesar 4,598. Untuk mencari $\mathrm{t}$ tabel pada signifikan 0,05 dengan derajat kebebasan $\mathrm{df}=\mathrm{n}-\mathrm{k}-1$ atau 76-2-1 = 73 maka diperoleh nilai untuk $\mathrm{t}$ tabel sebesar 1,984. Karena $\mathrm{t}$ hitung $(4,598)>\mathrm{t}$ tabel $(1,984)$, maka H1 ditolak,H0 diterima,artinya bahwa penilaian prestasi kerja secara parsial berpengaruh terhadap promosi jabatan.

Pengujian variabel promosi jabatan (b2) dengan hipotesis :

$\mathrm{H} 0=$ koefisien regresi penilaiasi prestasi kerja kerja secara parsial tidak berpengaruh terhadap promosi jabatan. 
$\mathrm{H} 1$ = koefien regresi penilaian prestasi kerja secara parsial berpengaruh terhadap promosi jabatan.

Berdasarkan hasil dari output $\mathrm{t}$ hitung diperoleh sebesar 3,248. Untuk mencari 00,5 dengan derajat pelatihan df $=n-k-1$ atau 76-2-1=73 maka diperoleh nilai untuk $\mathrm{t}$ tabel sebesar 1,984 . Karena $t$ hitung $(3,248)>t$ tabel ( 1,984),maka H0 ditolak, H1 diterima,artinya bahwa penilaian prestasi kerja secara parsial berpengaruh terhadap promosi jabatan.

\section{- Uji Secara Bersama-sama ( uji f )}

Uji-F atau uji koefesien regresi secara bersama-sama digunakan untuk mengetahui apakah secara bersamasama variabel dependen. Dalam hal ini untuk mengetahui apakah variabel penilaian prestasi kerja berpengaruh secara signifikan atau tidak terhadap promosi jabatan . Pengujian menggunakan tingkat signifikan 0,05 .

\section{Tabel 4.7}

ANOVA

ANOVA $^{a}$

\begin{tabular}{|c|c|c|c|c|c|c|}
\hline Model & & Sum of Squares & $\mathrm{Df}$ & Mean Square & $\mathrm{F}$ & Sig. \\
\hline & Regression & 4,645 & 2 & 2,323 & 7,185 &, $000^{\mathrm{b}}$ \\
\hline 1 & Residual & 226,593 & 18 & 12,588 & & \\
\hline & Total & 231,238 & 20 & & & \\
\hline
\end{tabular}

a. Dependent Variable: Pomosi Jabatan

b. Predictors: (Constant), Penilaian Prestasi Kerja

$\mathrm{H} 0: \mathrm{b} 1, \mathrm{~b} 2=0$, artinya secara bersama-sama tidak terdapat pengaruh yang positif dan signifikan dari variabel bebas $(\mathrm{X})$ yaitu berupa Penilaian prestasi kerja terhadap promosi jabatan sebagai variabel terikat (Y).

$\mathrm{H} 1: \mathrm{b} 1, \mathrm{~b} 2 \neq 0$, artinya secara bersama-sama terdapat pengaruh yang positif dan signifikan dari variabel bebas( ) yaitu berupa penilaian prestasi kerja terhadap promosi jabatan sebagai variabel terikat (Y).

H0 : Tidak adanya pengaruh penilaian prestasi kerja secara parsial terhadap promosi jabatan pada kantor Dinas Perhubungan Kota Palembang.

H0 : Tidak adanya pengaruh penilaian prestasi kerja secara bersama-sama terhadap promosi jabatan pada kantor Dinas Perhubungan Kota Palaembang

\subsection{Pembahasan}

Berikut ini adalah pembahasan hipotesis dari hasil penelitian dan pengelolaan data yang telah dilakukan;

1. Hipotesis pertama yang menyatakan bahwa "Diduga ada pengaruh yang signifikan antara penilaian prestasi kerja terhadap promosi jabatan pada kantor Dinas Perhubungan Propinsi Sumatera Selatan" Dapat diterima, hal ini didukung oleh hasil perhitungan Uji $\mathrm{F}$ di mana secara bersama-sama variabel tingkat penilaian prestasi kerja secara bersama-sama berpengaruh positif terhadap promosi jabatan pada kantor Dinas Perhubungan Propinsi Sumatera Selatan dilihat dari nilai Fhitung sebesar 7,185 dengan nilai signifikansi (sig) sebesar 0,000 dan dapat dilihat bahwa nilai signifikansi (sig) jauh lebih kecil dari 0,05 sehingga hal ini menjelaskan adanya pengaruh signifikan secara bersama-sama antara variabel independen terhadap variabel dependen. Dari penelitian ini dapat dikatakan bahwa kebijakan kantor Dinas 
Perhubungan Propinsi Sumatera Selatan haruslah dimulai dari inisiatif tingkat prestasi kerja. Sikap ataupun respon dari pihak kantor Dinas Perhubungan Propinsi Sumatera Selatan terhadap promosi jabatan haruslah tegas dan jelas dalam bentuk kebijakan tertulis.

2. Hipotesis kedua yang menyatakan bahwa "Diduga tingkat penilaian prestasi kerja dominan mempengaruhi promosi jabatan pada kantor Dinas Perhubungan Propinsi Sumatera Selatan tidak dapat diterima karena dari hasil perhitungan Uji $\mathrm{T}$ di mana variabel tingkat promosi jabatan memperoleh hasil $\mathrm{T}$ hitung 7,668 atau yang paling tinggi di atara variabelvariabel lainnya dengan nilai sig sebesar 0,000 yang jauh lebih kecil dari 0,05 sehingga hal ini dapat kita katakan bahwa variabel penilaian prestasi kerja merupakan variabel yang paling dominan mempengaruhi promosi jabatan pada Dinas Perhubungan Kota Palembang

\section{KESIMPULAN DAN SARAN \\ 5.1 Kesimpulan}

Berdasarkan pengamatan dan analisis terhadap data penelitian yang dilakukan. Maka peneliti mengambil penelitian sebagai berikut : bahwa penilaian prestasi kerja tidak terlalu signifikan mempengaruh terhadap promosi jabatan pada kantor Dinas Perhubungan Propinsi Sumatera Selatan", hal ini dapat dilihat dari analisis statistik :

a. Koefesien determinasi $\left(\mathrm{R}^{2}\right)$

Pada hasil $\mathrm{R}$ square $\left(\mathrm{R}^{2}\right)$ Didapat nilai sebesar 0,659 artinya persentase sumbangan pendidikan dan latihan terhadap prestaasi kerja karyawan $56,1 \%$ sedangkan sisa sebesar 96,5\% dipengaruhi oleh variabel lain yang tidak dimasukkan dalam penelitian ini.

b. Uji T (secara parsial)

Pada variabel penilaian prestasi kerja (X) diperoleh $t$ hitung diperoleh sebesar 4,598. Untuk mencari 00,5 dengan derajat penilaian prestasi kerja $\mathrm{df}=\mathrm{n}-\mathrm{k}-1$ atau 76-2-1=73 maka diperoleh nilai untuk $\mathrm{t}$ tabel sebesar 1,984 . Karena t hitung $(4,598)$

$>\mathrm{t}$ tabel $(1,984)$, maka H0 ditolak, H1 diterima,artinya bahwa penilaian prestasi kerja secara parsial berpengaruh terhadap promosi jabatan..

c. Uji F (secara bersama-sama)

Berdasarkan hasil dari output $F$ hitung diperoleh sebesar 7,185 Untuk mencari $F$ tabel pada signifikansi 0,05 dengan derajat kebebasan $\mathrm{df}=\mathrm{n}-\mathrm{k}-1$ atau $60-2-1=$ 57 maka diperoleh nilai untuk $F$ tabel sebesar 3,087. Karena $F$ hitung $(7,185)>F$ tabel $(3,087)$,maka H0 ditolak, H1 diterima, artinya bahwa penilaian prestasi kerja secara bersama-sama (simultan) berpengaruh terhadap promosi jabatan.

\subsection{Saran}

1. Pihak kantor perlu memberikan penilaian prestasi kerja terhadap karyawan untuk meningkatkan promosi jabatan.

2. Memberikan peraturan dan sanksi yang tepat untuk meningkatkan penilaian prestasi kerja bagi karyawan yang melanggar, hal ini untuk dapat meningkatkan ataupun mempertahankan kinerja pegawai yang ada.

\section{DAFTAR PUSTAKA}

As'ad, Moh. 2016. Psikologi Industri. Edisi keempat. Liberty Yogyakarta. 
Departemen Pendidikan dan

Kebudayaan. 2016. Kamus

Besar Bahasa Indonesia,

Edisi 3. Balai Pustaka Jakarta.

Dharma, Agus. 2017. Manajemen

Prestasi Kerja. Edisi Pertama

Rajawali, Jakarta.

Gibson, James L., Ivancevich,

Donnelly, Jr, 2017. Organisasi:

Perilaku, Struktur, Proses.

Edisi I. Bina Rupa Aksara, Jakarta.

Hamalik, Oemar. 2015. Psychologi Manajemen. Tri Gendakarya, Bandung.

Handoko, Hani. 2014. Manajemen Personalia. BPFE, Yogyakarta.

Hariandja, Marihot, T.E. 2014. Manajemen Sumber Daya Manusia, Grasindo. Jakarta.

Mangkunegara, A. Prabu. 2016. Evaluasi Kinerja SDM, Refika Aditama, Bandung.

Mangunhardjana, A.M. 2016. Mengembangkan Kreativitas, Terjemahan dari David Cambell. Kanisius, Jakarta.

Robbins, Stephen. P., 2016. Perilaku

Organisasi: Konsep,

Kontroversi, Aplikasi. Alih

bahasa: Hadyana.

Preinhallindo, Jakarta.

Semiawan, Conny, 2014. Memupuk Bakat dan Kreativitas Siswa Sekolah Menengah. Gramedia Jakarta. 